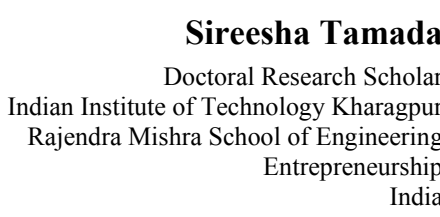

Manish Chandra

Doctoral Research Scholar Indian Institute of Technology Kharagpur Rajendra Mishra School of Engineering Entrepreneurship India

Prasenjit Patra

Doctoral Research Scholar Indian Institute of Technology Kharagpur Rajendra Mishra School of Engineering Entrepreneurship India

Sourabh Mandol

Doctoral Research Scholar Indian Institute of Technology Kharagpur Rajendra Mishra School of Engineering Entrepreneurship India

Debraj Bhattacharjee

DoctoralResearch Scholar Indian Institute of Technology Kharagpur Rajendra Mishra School of Engineering Entrepreneurship India

Pranab K. Dan

Associate Professor Indian Institute of Technology Kharagpur Rajendra Mishra School of Engineering Entrepreneurship India

\section{Modeling for Design Simplification and Power-Flow Efficiency Improvement in an Automotive Planetary Gearbox: A Case Example}

An approach for design simplification and improvement in power-flow efficiency of an automotive planetary gearbox is presented in this article. Integrated CAD-CAE model, formed on stick diagram representation of geartrain operation, is developed for gleaning efficient gearbox configuration. A stick diagram for a three-stage planetary gearbox is a case exemplified here. CAE/simulation for dynamic analysis is conducted to determine deformation in geartrain. Powertrain model of the vehicle, Saturn-SL1, is selected from NREL ADVISOR. The power flow efficiency for each gear ratio is computed using DelCastillo's principle, and deformation is analysed to identify suitable gear ratios. It is observed that designing gearbox with five ratios yields higher efficiency than with seven. The developed model is tested on MATLAB, with New Europian Driving Cycle, to specify best operating range.Higher efficiency range is underscored, that is, driving in second through fourth gear. The proposed approach specifies driving conditions and efficiency while designing a gearbox.

Keywords: Computer-aided design, computer-aided analysis, planetary gear set, total deformation, power flow efficiency, design simplification.

\section{INTRODUCTION}

This work presents an approach for obtaining design simplification and improving the mechanical powerflow efficiency of an automotive planetary gearbox. The gearbox is developed using CAD-CAE modeling, treating the stick diagram as its basis. The power-flow through the gear train and its members is indicated using a stick diagram, thereby, representing the operation of the gearbox. Gear train translates power from input to output in a gearbox and, therefore, this part has been considered for all the analysis performed here. Planetary gearboxes are mostly used for automatic transmission in lightweight vehicles [1]; however, other application areas have also been indicated in the literature [2]. Besides the conventional vehicle, the planetary transmission is used in the modern hybrid vehicle as a power-split device [3]. There are several reasons for its popularity, such as the compactness of the gear train, the capability of producing higher reduction ratios,

Received: April 2020, Accepted: June 2020

Correspondence to: Sireesha Tamada, Indian Institute of Technology Kharagpur, Rajendra Mishra School of Engineering Entrepreneurship, India

E-mail: mail2sireeshatamada@gmail.com doi: $10.5937 /$ fme2003707T

(C) Faculty of Mechanical Engineering, Belgrade. All rights reserved multiple gear ratios from single planetary gear set and higher torque carrying capacity [2].

In the case of automobiles, the transmission plays an important role as it provides the initial high torque to counter the vehicle inertia at the stationary condition. It also facilitates the engine to transmit the desired traction force to the wheels for required acceleration. The gear ratios, in the transmission system, act as a multiplier to the engine torque, which has a variable requirement depending on movement in different kinds of terrains involving road sole and conditions. A range of torque option for the transmission system in the vehicle is made available through multiple gear ratios as the desired gear ratio enables for optimal transmission efficiency. Each planetary gear set, in the form of a single mechanism, provides multiple gear ratios whereas multiple sets or multistage gear trains lend more speed options as used by the manufacturers for obtaining a compact transmission design in automobiles [4]. The number of speed options or the gear ratios and the respective value for each combination is critical in the gear mechanism design. Therefore, designing the gear train mechanism is the key to configure a transmission system [5].

Using heuristic or graph theoretic computational model help to obtain the best design solution points for mechanism synthesis, which is represented through the 
stick diagram. The scope of this paper is to develop the CAD-CAE model based on a select stick diagram and to carry out further analysis. The stick diagram developed in reference [6] is used as the basis for the present design. Therefore, only a very brief discussion regarding the computation model for the stick diagram or the mechanism synthesis has been made. Generally, two types of techniques are employed for mechanism synthesis; in many cases, the graph-based methods have been employed [7]. Heuristic synthesis of mechanism, however, can produce better results than graph theorybased methods in the event of specific application orientation such as automotive gearboxes [8,9]. The results of the heuristic or the graph-theoretic solution, obtained in a matrix form, representing the links and joints in a mechanism are used to configure the stick diagram or lever diagram for the mechanism [10]. The stick diagram illustrates the interaction between gear members, namely the ring, sun, planet gears, and carrier. But it does not convey any information if the physical configuration of the gear train will be suitable that is, whether the gears will mesh properly.

The geometric properties like teeth number, module, pressure angle and face width are necessary for the gear train configuration. The behaviour of the gear train mechanism in operating conditions can be determined if the property of the material used is known along with the geometric parameters. Now the use of digital technology, namely, computer-aided design (CAD) and computer-aided engineering (CAE) is rather common for mechanism design and testing. The digital processing is practically inevitable as it obviates the need to build and test multiple physical prototypes which are highly timeconsuming and expensive. The result of CAE analysis carried out with defined operating conditions as per a driving cycle is useful for mechanism design improvement. The analysis has been extended to accommodate variable loading conditions for obtaining information regarding the behavior of the mechanism which has been used in the design. Simplification and efficiency have always been a matter of interest in design. Design simplification is realised by using pertinent engineering information, and such improvement can be achieved in several ways. This simplification of design can be achieved either by removing a part or by improving the fetchers of the system [11]. Such simplifications can be construed in terms of diverse measures as defined with a reduction in product cost and enhancement in product reliability [12], where Kwon et al. simplifies a highly complex CAD model by eliminating some selected components of the model [13]. Rassokha and Isaychev [14] show that the reduction in clutch operation cost, driver fatigue, and increment in operation reliability can be achieved by simplifying gearbox design. Spur gear mechanism simplification, based on stress value analysis, has been carried out by Osakue [15]. In this article, the design simplification is exemplified as a reduction in the number of components and accessories and improvement in power flow efficiency. The deformation of gear train has been studied, and findings suggest that it has a bearing on the power flow efficiency as well as on the architecture.
Total def ormation, considering the geometry, material and the angular speed is treated as the measure of the change in the system or the gear train; and the computational details for the same is provided in Section 3.1. The reason for considering total deformation is that it affects the transmission efficiency as the contact characteristics impair power transfer between gear members due to deformation in the gear tooth $[16,17]$. Power loss in the powertrain is caused by such deformation of the mechanism or the gear train during operation. The deformation causes non-uniform load or torque distribution in a gear-pair and produces a cumulative effect due to the meshing of multiple gears, on the power transmission. To reduce power loss or error in transmission, the maximum load that causes deformation should be taken into account while designing the powertrain, which will be suitable for a given operating condition. The transmission load is to be restricted within allowable torque and speed, for better life of the system $[18,19]$. Therefore, measurement of the total deformation of the gear train mechanism to be used under different dynamic conditions is required.

The use of deformation information for design improvement is available in the literature, and a summary is provided here. The study of deformation patterns through modal analysis and NVH (noise, vibration, and harshness) test, was conducted on a single planetary gear set, thatcan be found inreference [20]. The study concludes that static transmission error occurs due to deformation in the planetary gear set. Deformation in gear leads to improper mashing between pairs, and this affects the sliding speed and the friction force, causing a reduction in transmission efficiency of a planetary gear train [21]. Deformation was studied by Ambarisha and Parker [22], and the work used finite element models to analyse the nonlinear dynamics of planetary gears. The bifurcation and chaos analysis of gear-bearing, which is similar to epicyclic gear with time-varying stiffness have been carried out by Xiang [23], and a similar study for multistage planetary gear train was conducted by Lee [24]. Nonlinear dynamic analysis, involving deformation criteria of a planetary gear system with multiple clearances was reported [25], while Chen and Shao [26] investigated the dynamic response of planetary gears taking into account the ring gear flexibility and tooth deformation, as well as failure. The accuracy of lumped-parameter and finite element models was demonstrated by experimentation [27], and the work delineated several designs and modeling characteristics of planetary gears. The work cited in reference [28] shows that the gear tooth failure occurs if contact stresses are higher than the wear strength of the gear and also that the maximum contact stress decreases with an increasing module of gear. A similar observation was reported in a few other articles [29,30], while in the former, the author investigates the effect of module, power, and speed on the contact stress. All the studies referred in this paragraph considered deformation, some way or other as a criterion. An essential determinant of deformation is the yield strength that characterises the material. 


\section{METHODOLOGY}

The methodology presented here needs to be explored as to whether the deformation can influence power flow efficiency or the design simplification aspect, which has been addressed in this article. For this purpose, a 3D digital model of a stick diagram, as referred below, is created, using CAD and on which the engineering analysis (CAE) has been conducted. The methodology is explicated with a case example, that is, by selecting the stick diagram of a gear train operation which in this case is retrieved from reference [6]. The stick diagram, drawn up based on the gear ratios that regulates speed and torque is depicted in Figure 1 and the gear ratios for different power flow conditions are presented in Table 1.

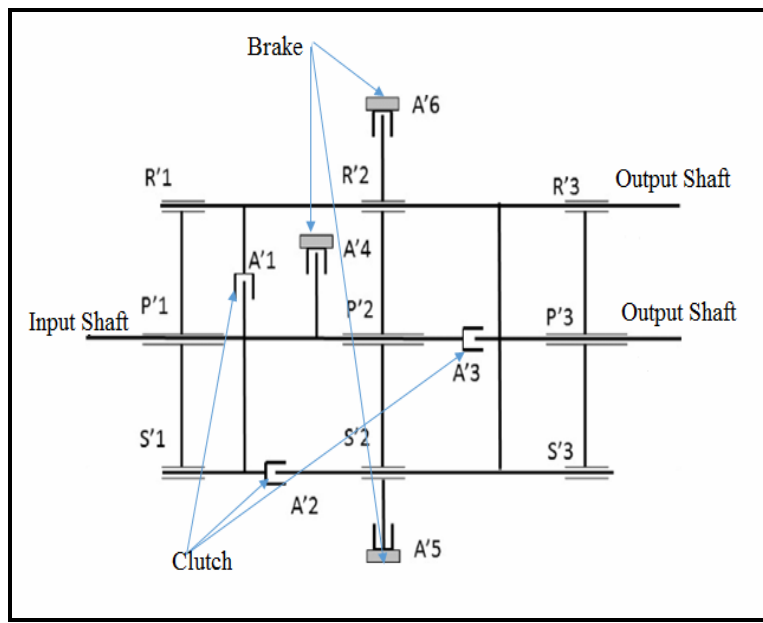

Figure 1: Stick diagram of the Planetary Gearbox

Stick diagram in the above figure depects the threestage planetary gearbox configuration, where the ring gear, planet gear and sun gear are denoted as R, P and S respectively. The gearbox has three clutches (A'1, A'2 and A'3) and three brakes (A'4, A'5 and A'6) and they are used to change gear. Clutches are engaged to transmit rotational motion from one gear element to another gear element and brakes are used to restrict the motion of gear elements. Two output shafts of the gearbox provide different set of gear ratios, separetly through each of them. The rotational motion transfer through the gear elements, using clutches and brakes is explicated here choosing the second gear as example. In this example case, the rotational motion enters through planet gear and the power goes out through the ring gearboth plased in the first stage. For this, A'1 and A'5 are engaged, where A' 4 is in disengaged mode. The rotational motion of the first stage ring gear is transferred to the planet gear in the second stage which likewise is transferred to the ring gear of the same stage. Finally the motion of the ring gear of the second stage is transferred to the ring gear of the third stage for output power delivery. This explication on tracing the powerflow for the second gear will help visualization of power transmission for any other gear engagement.It may be noted, regarding Table 1, that a particular type of gear element remains locked when power is flowing as input in one gear element and is transmitted in the other as output. For example, 'RPS' signifies that the ring gear $(\mathrm{R})$ is in the locked (non-rotating) condition where power flows as input to the planet carrier (P) and is transmitted as output through the sun gear (S) for any given stage. It may also be noted that a dash ('- ') in Table 1 indicates no locking of gears, that the gear set in that particular stage is acting as an idler transmitting the same rotational speed between the preceding and succeeding stages. The number of teeth, which determines the gear ratio between the meshing gears is presented in Table 2, according to the stick diagram.

Table 1: Interaction between the elements

\begin{tabular}{|c|c|c|c|}
\hline Stage 1 & Stage 2 & Stage 3 & Gear ratio \\
\hline RPS & - & SRP & 3.6 \\
\hline SPR & SPR & SPR & 2.54 \\
\hline SPR & SPR & - & 1.80 \\
\hline RPS & - & RSP & 1.48 \\
\hline RPS & RPS & SRP & 1.11 \\
\hline SPR & SRP & - & 0.86 \\
\hline SPR & SRP & SRP & 0.61 \\
\hline RPS & PRS & RSP & -3.3 \\
\hline
\end{tabular}

Table 2: Initial teeth number of the gear elements

\begin{tabular}{ccccc}
\hline Parameters & Stage & S & P & R \\
\hline Teeth number & First PGS & 22 & 34 & 90 \\
Teeth number & Second PGS & 40 & 25 & 90 \\
Teeth number & Third PGS & 35 & 25 & 85 \\
\hline
\end{tabular}

Both material and geometric information are required to design a multistage planetary gear train, and it is necessary to check the suitability of the design for a particular application which is for automotive application in this work. Structural steel is chosen here, as the material with its properties specified in terms of; Young modulus, Poisson ratio, tensile yield strength, compressive yield strength, tensile ultimate strength. Geometric properties are included in the model comprising of teeth number, gear module, pressure angle and face width for devising the gear train configuration. First, the CAD model of the gear train is developed using SolidWorks software, adjusting the number of gear teeth for proper meshing. To ensure proper meshing a minor modification has been incorporated, by increasing one tooth in the sun and ring gear elements in the first and second stage, and this difference in teeth number can be observed in Table 3. Next, this CAD model has been 'imported' in ANSYS software for simulation (CAE) to find total deformation. For the CAE analysis, a realistic or standard speed profile in the form of a graph, indicating vehicle speed versus time is considered, and the NEDC driving cycle is chosen as the reference for this purpose. The NEDC driving cycle is a popular reference and is used by most of the countries in the world. For performance comparison of the proposed gear train model that evolved from CAE analysis with the one simply based on the stick diagram, the Saturn SL1 model available in the National Renewable Energy Limited (NREL) ADVISOR module of MATLAB is chosen.

The vehicle speeds with the unit in kilometre per hour at different time points along with seven forward gear ratios obtained from the stick diagram are provided as inputs to ADVISOR software to gaze the corresponding engine speed. The engine speeds so obtained for seven gear ratios are used for CAE along with the geometric 
information to find the values of component deformations. The power flow efficiency for each gear ratio is computed using the relevant formulation [31]. Now the deformations as presented in Figure 5 and the power flow efficiency as presented in Table 5 is compared to gauge the effect the former can have on the latter. The motive behind expelling low power flow efficiency values is to discard the corresponding gear ratios to improve the overall efficiency of the gear train. For this purpose, only five gear ratios are selected to design the geartrain. The new modified design has been compared with the one. That was based only based on stick diagram devoid of any CAD/CAE application. Now to map the performance of the improved design one more simulation run is conducted displaying the values for gear ratio, vehicle speed, and power-flow efficiency. A sample profiling shows that the deformation is most prominent on the tooth of the gear that corroborates the general perception as well, as shown in Figure 5.

\subsection{Maximum total deformation}

For a particular gear ratio, the vehicle can have a prescribed speed range and the torque varies based on the speed at any time point. This torque causes deformation at every interval point. Total deformation is computed at each such interval points; however, for the largest deformation, the maximum value of the total deformations is chosen for designing. Total deformation can be expressed as a square root of the summation of the square of deformation in $\mathrm{x}, \mathrm{y}$ and $\mathrm{z}$ directions in threedimensional space and is presented in Equation (1).

$$
d_{\text {total }}=\sqrt[2]{d_{x}^{2}+d_{y}^{2}+d_{z}^{2}}
$$

where, $d_{\text {total }}$ is the total deformation and $d x, d y, d z$ are the directional deformations respectively.

\subsection{Power flow efficiency}

Power flow efficiency is a determinant of transmission efficiency and is a key parameter of the planetary gear train. It is a determinant of the power density of transmission systems. The efficiency which is measured here is the power flow efficiency [31]. Efficiency for each gear ratio is necessary for measuring the average efficiency of the gearbox. According to this method, the power flow efficiency should be greater than $90 \%$ for a feasible design of the gear ratio. The use of this formula for gearbox enumeration can befound in [32] and [10]. The mathematical expression for the power flow efficiency is provided in Equation (2).

$$
\eta=1-\sum_{j=1}^{p}\left(1-\eta_{0}\right)\left|T_{\text {in }}\left(\omega_{\text {in }}-\omega_{\text {out }}\right)\right|
$$

where $\eta$ is the power flow efficiency of the planetary gear train, $p$ is the total number of stages, $j$ is indicating the stage, $\eta_{0}$ is the mechanical efficiency of the individual planetary gear set, $T_{i n}$ is the input torque at any particular stage, $\omega_{\text {in }}$ is the input rotational velocity at a particular stage and $\omega_{\text {out }}$ is the output angular velocity from a particular stage. The efficiency of planetary gear set $\left(\eta_{0}\right)$ depends on the losses due to gear interaction. Losses in any geared transmission can be categorized into load dependent power loss, also termed as mechanical power loss and the other is the load independent power loss which is also called spin loss [33]. The location of mechanical losses are at the contact of the mating surface of meshed gears and at the bearing. Such losses occurs due to relative sliding and rolling action of the electrodynamic lubricant film at the aforementioned contact interfaces that is interpreted as friction. This contact friction is very low under unloaded condition with the components surrounded in medium, namely oil, air and mixture of oil and air. When in oil it is termed as churning loss and in other cases it is known as windagelosses. On the other hand, the spin loss of a gear set are comprised of drag losses and viscous losses. Both are caused by rotation of components in medium. Pocketing of the fluid at the gear mesh interfaces results in drag losses where the viscous losses are caused by the rolling of bearing besides some minor secondary losses originating from shifters or oil films. Considering losses, the efficiency at sun to planet gear is 0.97 and planet to ring gear as 0.98 . These mechanical efficiency values are used as constant in the computation heare. For computational simulation the temperature of transmission lubrication oil is considered as $60^{\circ} \mathrm{C}$ according to reference[34] for optimal estimation.

\subsection{Planetary gear train design}

A configuration of a planetary gear set, depicted in Figure 2, is composed of sun, planet and ring gear labelled as $\mathrm{S}, \mathrm{P}, \mathrm{R}$ respectively. The number of teeth in these three gears is denoted as $Z_{s}, Z_{p}$, and $Z_{R}$. The torque $(\tau)$ and rotational velocity $(\omega)$ are determined by the number of teeth $(Z)$ and the relations are enumerated in Equations 3 through 6.

$$
\begin{aligned}
& \tau_{r}=\tau_{p} \times \frac{z_{r}}{z_{r}+z_{s}} \\
& \tau_{p}=\tau_{r}+\tau_{s} \\
& \tau_{s}=\tau_{p} \times \frac{z_{s}}{z_{r}+z_{s}} \\
& \frac{\omega_{r}-\omega_{s}}{z_{s}+z_{r}}=\frac{\omega_{p}-\omega_{s}}{z_{r}}
\end{aligned}
$$

Proper meshing is critical to designing a planetary gear and the problem can be solved by considering the rules as presented in Equations 7 through 10 which are long-established formulae, used in several technical documents, and is available in references [35-37] and known as the condition for coaxiality, adjacency and conjunction[38].The first rule shows the relation between the teeth numbers of the planetary gear elements. The other two rules determine the teeth number and the angle between the planet gears. Here $m$ is the module of the gear and $\theta$ is half of the angle between the adjacent planet gears, which is noted in Figure 2.

Rule 1:

$$
Z_{R}=Z_{S}+2 Z_{p}
$$




$$
\begin{aligned}
& \frac{z_{S}+z_{R}}{n}=\text { integer } \\
& \frac{\left(z_{S}+z_{R}\right) \theta}{180}=\text { integer }
\end{aligned}
$$

Rule 3:

$$
Z_{R} 2\left(Z_{S}+Z_{R}\right) \sin \left(\frac{190}{n}\right)
$$

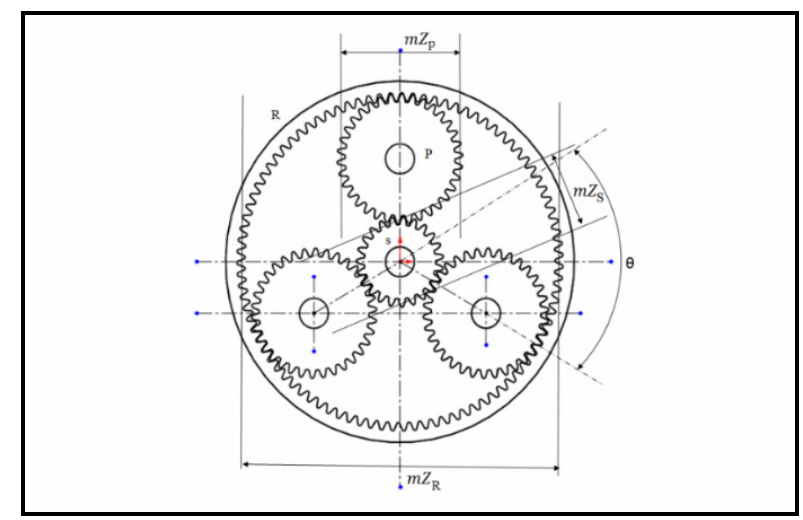

Figure 2: Three rules for gear teeth selection

The values of the teeth number as available in Table 2 satisfy Equation 7 but does not comply with Equation 8. Hence, for satisfying Equations 7 through 10 the teeth numbers are selected and the values are provided in Table 3. The values for the module, face width of gear, pressure angle and the nominal diameter of the shaft, for realistic design is gleaned from reference [39].

Table 3: The Geometric parameters used in the CAD model

\begin{tabular}{ccccc}
\hline Parameters & PGS & Sun & Planet & Ring \\
\hline Teeth number & $1 \mathrm{st}$ & 23 & 34 & 91 \\
Module & $1 \mathrm{st}$ & & 3 & \\
Pressure Angle & $1 \mathrm{st}$ & & 20 & \\
Face Width & $1 \mathrm{st}$ & & 20 & \\
Teeth number & 2nd & 41 & 25 & 91 \\
Module & 2nd & & 3 & \\
Pressure Angle & 2nd & & 20 & \\
Face Width & 2nd & & 20 & \\
Teeth number & 3rd & 35 & 25 & 85 \\
Module & 3rd & & 3 & \\
Pressure Angle & 3rd & & 20 & \\
Face Width & 3rd & & 20 &
\end{tabular}

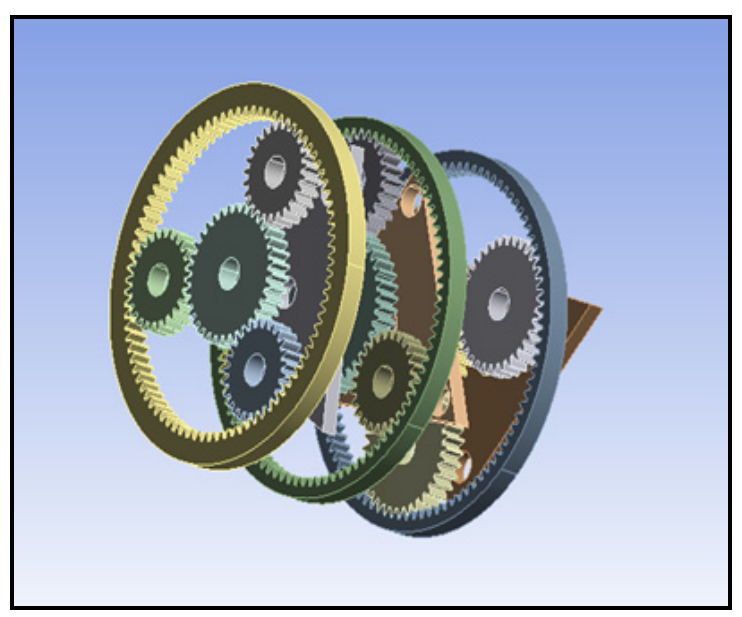

Figure 3: CAD model of designed planetary gear train
The materials used are a steel alloy with the mechanical properties as; Young modulus: $2 \mathrm{E}+11 \mathrm{~Pa}$, Poisson ratio 0.3 , Tensile yield strength $2.5 \mathrm{E}+8 \mathrm{~Pa}$ Compressive Yield Strength 2.5E+08 Pa, Tensile ultimate strength 4.6E+08 Pa. The CAD model of the three-stage planetary gear train system prepared in SolidWorks software presented in Figure 3 and analysed in ANSYS.

\section{SIMULATION AND DESIGN ANALYSIS:}

\subsection{Total deformation measurement}

The condition necessitates a dynamic analysis, and therefore computer-aided engineering or simulation has been conducted to find deformation. The simulation has been carried out in ANSYS 18.2 software using the rigid dynamics solver module, on the gear train, illustrated in the planetary gear train design subsection. It has been performed for each gear ratio taking the rotational speed as input for finding the total deformation for the respective gear ratio. An important fetcher in the analysis is the selection of a driving cycle that represents the driving pattern and is deployed for vehicle performance testing. A standard driving cycle is always preferable over any arbitrary driving pattern for such an analysis. The NEDC driving cycle is a very popular one used in most countries, to access the vehicle performance and hence this driving cycle is selected for analysis in this study. The speed $(\mathrm{km} / \mathrm{hr})$ versus time (second) graph of the NEDC driving cycle is presented in Figure $4 \mathrm{a}$ and for observing the engine speed radian per second (rps) versus time, obtained from the simulation, is presented in Figure 4b.

The vehicle model Saturn SL1 specified with the parameter's value as obtained from NREL ADVISOR in Table 4, is chosen for the analysis. The simulation has been done in the system with Windows 10, 16GB RAM, Intel i7. The maximum total deformation, derived as explained in Section 2.1 while considering the modified gear ratio, due to readjustment of the number of teeth for proper meshing and the computational results from simulation is explained in the next part of this subsection. It has been explained in Section 2.3 that the gear ratio may slightly vary from the gear ratios based on the stick diagram because of the adjustment of teeth number for proper meshing.
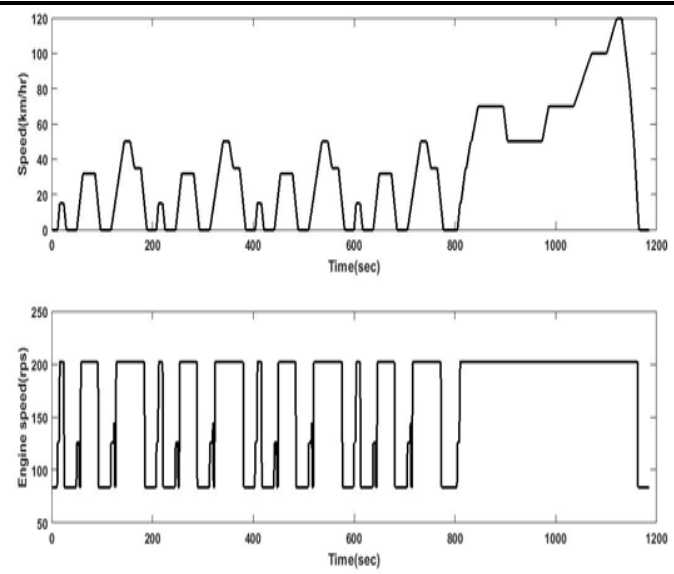

Figure 4: Simulation (a)Input Driving Cycle and(b) Engine Speed 
Table 4: Vehicle Model Details

\begin{tabular}{lc}
\hline \multicolumn{1}{c}{ Parameters } & Value \\
\hline Vehicle Mass & $1200 \mathrm{Kg}$ \\
Wheels per axle & 2 \\
Horizontal distance from CG to front axle & $1.4 \mathrm{~m}$ \\
Horizontal distance From CG to rear axle & $1.6 \mathrm{~m}$ \\
CG height about the Ground & $0.5 \mathrm{~m}$ \\
Front area & $2 \mathrm{~m}^{2}$ \\
Drag coefficient & 0.4 \\
Gravitational acceleration & $9.81 \mathrm{~m} / \mathrm{s}^{2}$ \\
Air density & $1.18 \mathrm{~kg} / \mathrm{m}^{3}$ \\
Engine maximum power & $75 \mathrm{~kW}$ \\
Engine peak efficiency & 0.34 \\
Wheel radius & $0.3 \mathrm{~m}$ \\
\hline
\end{tabular}

The dynamic analysis performed with ANSYS rigid dynamics solver module provides maximum total deformation values but it cannot generate the deformation heat map. It is, however, possible to obtain the deformation heat map through astatic analysis in ANSYS to identify the location and deformation pattern with a sample case. The two deformation values $0.0865 \mathrm{~mm}$ and 0.027004 $\mathrm{mm}$ for corresponding gear ratios 0.60 and 2.45 are the largest among the total seven in number.

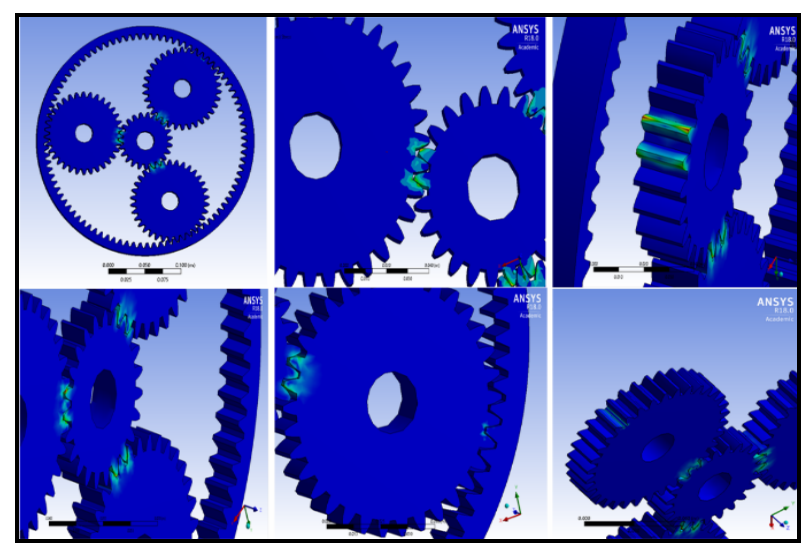

Figure 5: Deformation visualisation through static structural analysis

The lowest deformation value is chosen for static analysis to obtain the location and magnitude of deformation, even for the lower total maximum deformation among the two mentioned above. The heat map of the static analysis for the sample case is provided in Figure 5 visualisation for deformation, resulted from static structural analysis. It shows that the deformation is largest on the tooth profile of the gear member.

\subsection{Gear efficiency calculation}

The power-flow efficiency, using Equation 2 is computed for each gear ratio and is presented in Table 5 .

Table 5: Power-flow efficiency calculation

\begin{tabular}{|l|l|l|l|l|l|l|l|}
\hline Gear ratio & 3.43 & 2.45 & 2.01 & 1.42 & 1.00 & 0.83 & 0.60 \\
\hline Efficiency & 0.94 & 0.93 & 0.99 & 0.95 & 0.97 & 0.95 & 0.94 \\
\hline
\end{tabular}

The computational process of power-flow through the gear members at multiple stages is exemplified for the gear ratio 1.00 as can be seen in the stick or lever diagram depicted in Figure 6. Computed values for torque $(\tau)$ and speed $(\omega)$, along the power flow path including the input and output shafts, using Equations (3) through (7), can be found in this diagram. The efficiency values of the 'sun to planet' gear and 'planet to ring' gear is 0.97 and 0.98 respectively, as indicated by Xie et al, 2015 [10] is used here for computing torque and rotational velocities in the power flow. Accordingly, the efficiency $\left(\eta_{0}\right)$ of a planetary gear set is the product of the efficiencies of the individual gears that is 0.95 . The rotational velocity of the locked element in the planetary gear train is zero while there will be a torque value at such locations. The direction of rotation in the power flow, viewing from a particular point, is treated as positive if it is clockwise and negative if it is counterclockwise and the same signs are used for torque. The change of power is 0.71 for the example case with gear ratio 1.00 , derived from the power flow efficiency formula in Equation 2. Now the loss fraction of single planetary gear set is 0.05 since its efficiency, as mentioned earlier is 0.95 and hence the loss in power change is a product of the change of power and the loss in the planetary gear set, which is 0.035. Therefore, the overall power flow efficiency is equal to 0.965 or rounded off to 0.97 . The power flow efficiencies, following the same computational approach, for all gear ratios are furnished in Table 5.

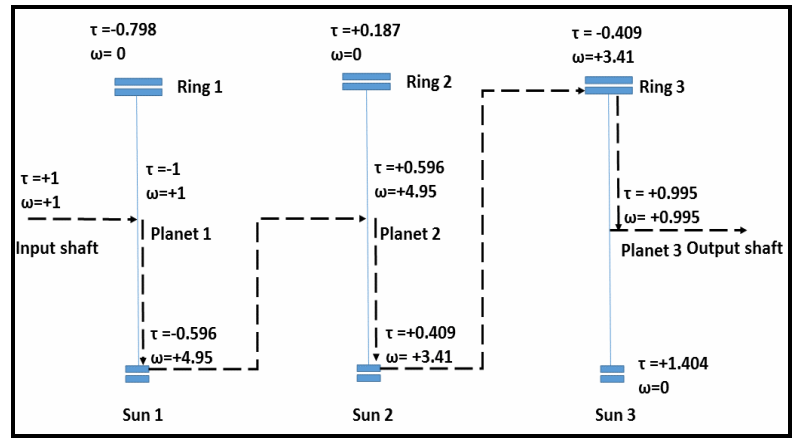

Figure 6: Calculation of power-flow efficiency

\section{REFORMULATION OF DESIGN AND TESTING}

By comparing the results of the power flow analysis and maximum total deformation, the ratios for the second and seventh gear exhibit the lowest efficiencies and largest deformation. The efficiency values for these two gears are 0.93 and 0.94 and the rest of the gears, except the first gear, are having efficiencies above 0.94 , as shown in Table 5 and the deformation values are relatively low. The first gear is having an efficiency of 0.94 which is the same as that of gear number seven but with low deformation. To improve the overall efficiency of the gear train, as described in the methodology section, two gears namely second and seventh are discarded to reformulate the design while retaining the first gear with the consideration that it carries the largest torque required during start. Therefore, the design has been reformulated with five gear ratios, that is, 3.43, $2.01,1.42,1.00$ and 0.83 and their interaction is presented in Table 6.

The proposed design is tested using the same NEDC driving cycle. By conducting the simulation in NREL ADVISOR again, the gear selection pattern and the power flow efficiency map are obtained as depicted in 
Figure 7 and Figure 8 respectively. It can be seen from Figure 10 that the efficient zone of operation is between the second and fourth gear with a speed range of 20 $\mathrm{km} / \mathrm{hr}$ to $50 \mathrm{~km} / \mathrm{hr}$. The salient point of this new design is 'design simplification'. This requires only one output shaft connecting to drive shaft instead of two concentric shafts required in the stick diagram-based design which can be read from Table 6 and Table 1. In Table 6, the output from the third or final stage through the planet gear $(\mathrm{P})$ for all gear ratios which can be clarified from the description embodied in the first paragraph of the methodology section. But in Table 1, it can be seen that the output from stage three is from two output shafts, one from the planet carrier $(\mathrm{P})$ other from the Ring gear (R) to cover all seven forward gear ratios.

Table 6: Final gearbox model gear member interactions

\begin{tabular}{cccc}
\hline Stage 1 & Stage 2 & Stage 3 & Gear Ratio \\
\hline RPS & - & SRP & 3.43 \\
SPR & SPR & - & 2.01 \\
RPS & - & RSP & 1.42 \\
RPS & RPS & SRP & 1.00 \\
SPR & SRP & - & 0.83 \\
RPS & PRS & RSP & -3.3 \\
\hline
\end{tabular}

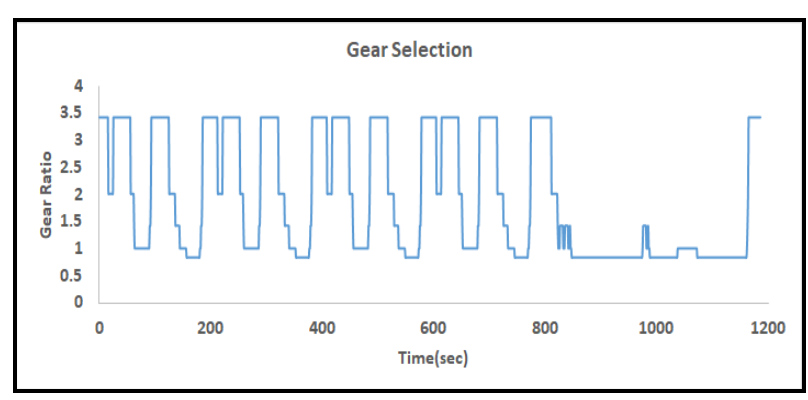

Figure 7: Gear selection in NEDC driving cycle

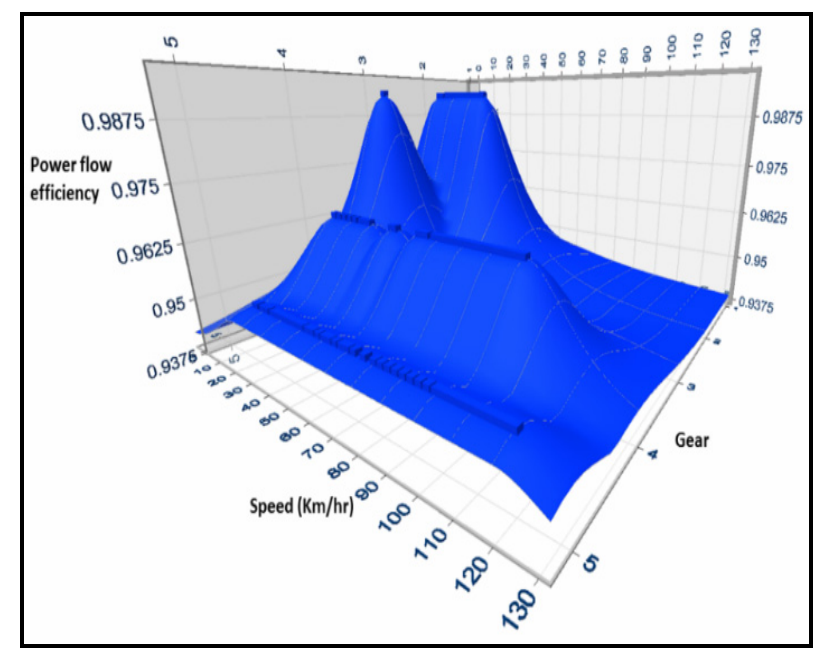

Figure 8: Power flow efficiency in speed variation of the vehicle

\section{RESULTS AND DISCUSSION}

Based on $\mathrm{CAD} / \mathrm{CAE}$ approach, the reconfigured gear train requires only one output shaft to be connected to drive shaft, thereby eliminating the need for another concentric output shaft that was required in the initial design. This results in a significant design simplification during modeling the five-speed gearbox instead of seven forward speed. The average power-flow efficiency is 0.96 against the initial efficiency of 0.95 , yielding an improvement of about $1 \%$. The maximum gear ratio for both cases is the same. The minimum gear ratio of the initial design was 0.61 , which for the proposed design is 0.83 . While it indicates a compromise on the highest speed it does not affect much as the efficient region is between the second and fourth gear that will operate at higher gear ratios. Another important feature is a significant reduction in the average maximum total deformation which, in the proposed design is 1.72 microns against 52.16 microns in the initial design.

\section{CONCLUSION}

The stick diagram alone is unable to yield the most efficient design for a particular driving condition with the speed range and respective gearing, as observed from the findings of the case example. The interpretations of findings analysed from the CAD-CAE model are that higher average efficiency can be achieved with a lesser number of gear ratios in the design of an automotive planetary gearbox. The proposed approach of design leads to the design simplification by reducing the number of output shafts for transmitting power to the driveshaft in a vehicle. Elimination of a concentric shaft would need lesser mechanical attachments and accessories, and thereby aids in reducing the weight of the gearbox assembly.

\section{REFERENCES}

[1] Kouroussis, G., Dehombreux, P., and Verlinden, O., (2015) Vehicle and Powertrain dynamics analysis with an automatic gearbox, Mechanism and Machine Theory, 83,109-124.

[2] Kim, W., Lee, J. Y., \& Chung, J. (2012). Dynamic analysis for a planetary gear with time-varying pressure angles and contact ratios. Journal of Sound and Vibration, 331(4), 883-901.

[3] Rotella, D., and Cammalleri, M., 2018, " Power losses in power-split CVTs: A fast black-box approximate method., Mechanism and Machine Theory, Vol. 128, pp. 528-543.

[4] Paroche, S., Deshmukh, H., Kandreegula, S. K., \& Muley, A. (2018). Finite Element Simulation and Validation of Planetary Gear System (No. 2018-280027). SAE Technical Paper.

[5] Pan, C. H., \&Moskwa, J. J. (1995). Dynamic modeling and simulation of the Ford AOD automobile transmission (No. 950899). SAE Technical Paper.

[6] Tamada, S., Bhattacharjee, D. and Dan P.K., Modeling and Formulation of Optimal Clutching Sequence in Automatic Transmission,2018 IEEE Vehicle Power and Propulsion Conference (VPPC), Chicago, IL, USA.

[7] Shanmukhasundaram, V. R., Rao Y. V. D., and Regalla S., P., 2019, Enumeration of displacement graphs of epicyclic gear train from a given rotation graph using concept of building of kinematic units, Mechanism and Machine Theory, Vol. 134, pp. 393-424. 
[8] Chew, M., Shen, S. N. T., \&Issa, G. F. (1995). Kinematic structural synthesis of mechanisms using knowledge-based systems. Journal of mechanical design, 117(1), 96-103.

[9] Eichhoff, J. R., \& Roller, D. (2016). Designing the same, but in different ways: determinism in graphrewriting systems for function-based design synthesis. Journal of Computing and Information Science in Engineering, 16(1), 011006.

[10]Xie, T., Hu, J., Peng, Z., \& Liu, C. (2015). Synthesis of seven-speed planetary gear trains for heavy-duty commercial vehicle. Mechanism and Machine Theory, 90, 230-239.

[11] Duarte, R., Mesnard, M., Ramos, A., Nadeau, J. P., \& Perry, N. (2018). Designing simplification strategy for solutions analysis and selection at the architectural design stage. Procedia CIRP, 70(1), 25-28.

[12]Krayner, N., \& Katz, R. (2018). Measuring Simplicity in Mechanical Design. Procedia Manufacturing, 21, 878-889.

[13] Kwon, S., Kim, B. C., Mun, D., \& Han, S. (2015). Graph-based simplification of feature-based threedimensional computer-aided design models for preserving connectivity. Journal of Computing and Information Science in Engineering, 15(3), 031010.

[14] Rassokha, V., \&Isaychev, V. (2017). New design of the automobile automatic gearbox providing driving simplification and driver fatigue decrease. Transportation Research Procedia, 20, 544-549.

[15] Osakue, E. E. (2016, November). Simplified Spur Gear Design. In ASME 2016 International Mechanical Engineering Congress and Exposition (pp. V011T15A018-V011T15A018). American Society of Mechanical Engineers.

[16] Peng, S., Ding, H., Zhang, G., Tang, J., \& Tang, Y. (2019). New determination to loaded transmission error of the spiral bevel gear considering multiple elastic deformation evaluations under different bearing supports. Mechanism and Machine Theory, 137, 37-52.

[17] Osakue, E. E., Anetor, L., and Harris , K. (2020) A parametric Study of Friction of Load Influence in Spur Gear Bending Resistance, FME Transactions, Vol. 48, pp. 294-306.

[18] Tsai, S. J., \& Ye, S. Y. (2018). A computerised approach for loaded tooth contact analysis of planetary gear drives considering relevant deformations. Mechanism and Machine Theory, 122, 252-278.

[19]Ristic ，D.,S. and Ktamberger, J.(2014) , Gear Tooth Rooth Stress and Fillet Radii Dependence, FME Transactions, Vol.42, pp. 323-328.

[20] Kahraman, A. (2001). Free torsional vibration characteristics of compound planetary gear sets. Mechanism and machine theory, 36(8), 953-971.

[21] Yimin, S., Xuzhong, L., Hongwu, L., Yan, C. and Jin, X., 2018, October. Efficiency Analysis of Planetary Gear Train under Ring Gear Deformation. In 2018 18th IEEE International
Conference on Control, Automation and Systems (ICCAS) (pp. 1409-1413).

[22] Ambarisha, V. K., \& Parker, R. G. (2007). Nonlinear dynamics of planetary gears using analytical and finite element models. Journal of sound and vibration, 302(3), 577-595.

[23] Xiang, L., Jia, Y., \& Hu, A. (2016). Bifurcation and chaos analysis for multi-freedom gear-bearing system with time-varying stiffness. Applied Mathematical Modelling, 40(23-24), 10506-10520.

[24]Lee, S. et al. A systematic approach for dynamic analysis of vehicles with eight or more speed automatic transmission. Journal of Dynamic Systems, Measurement, and Control, 136(5), 051008.

[25] Sun, T., Hu, H. (2003). Nonlinear dynamics of a planetary gear system with multiple clearances. Mechanism and Machine Theory, 38(12), 1371-1390.

[26]Chen, Z., \& Shao, Y. (2013). Dynamic simulation of planetary gear with tooth root crack in ring gear. Engineering Failure Analysis, 31, 8-18.

[27] Ericson, T. M., Parker, R. G. (2013). Planetary gear modal vibration experiments and correlation against lumped-parameter and finite element models. Journal of sound and vibration, 332(9), 2350-2375.

[28]Hassan, A. R. (2009). Contact stress analysis of spur gear teeth pair. World Academy of Science, Engineering and Technology, 58(1), 597-602.

[29] M. Raja Roy, 2014, "Contact pressure analysis of spur gear using FEA", International Journal of Advanced Engineering Applications (IJAEA), Vol.7 Issue 3, pp.27-41.

[30] Yadav S.H., 2013, "Failure investigation of planetary gear train due to pitting", International Journal of Mechanical Engineering and Robotics (IJMER), Vol.1, Issue 2, pp.86-92.

[31] Del'Castillo, Jose M., The analytical expression of the efficiency of planetary gear trains, Mechanism and Machine Theory, Vol. 37, pp.197-214, 2002.

[32] Bhattacharjee, D, Bhola, P, Dan, P. K., A heuristic synthesis of multistage planetary gearbox layout for automotive transmission, Proceedings of the Institution of Mechanical Engineers, Part K: Journal of Multi-body Dynamics, Vol. 233, No. 2, pp. 336-347, 2018.

[33] Talbot, C., D, Kahraman, A., and Singh, A., (2012) An Experimental Investigation of the Efficiency of Planetary Gear Sets,journal of Mechanical Design, Vol. 34, 021003-1-7.

[34] Nutakor, C et al. (2018) Development and validation of an integrated planetary gear set permanent magnet electric motor power loss model. Tribology International, Vol. 124, pp. 34-45.

[35]Zou, N., Wei, Y., Chang, S., \& Zhou, D. (2015, December). Single Planetary Mechanism Teeth Matching Conditions. In 2015 International Conference on Advanced Manufacturing and Industrial Application. Atlantis Press.

[36] An, Q., Suo, S., Yang, J., Wu, C., \& Yan, C. (2018, July). Program Design for the $3 \mathrm{~K}$ Planetary Gear 
Mechanism with more than Three Planet Gears. In IOP Conference Series: Materials Science and Engineering (Vol. 394, No. 3, p. 032127). IOP Publishing.

[37] Plekhanov, F., and Goldfarb V., (2016) Rotational Designs of Planetary Transmissions, Geometry of Gearing and Strength Parameters, Theory and Practice of Gearing and Transmission, Vol.34 pp.285-300, Springer.

[38] Troha, S., Stefanović-Marinović, J., Vrcan, Ž., Milovančević, M. (2020). Selection of the optimal two-speed planetary gear train for fishing boat propulsion, FME Transactions, Volume 48, No. 2, pp. 397-403.

[39] Bozca, M., (2010) Torsional vibration model-based optimisation of gearbox geometric design parameters to reduce rattle noise in an automotive transmission. Mechanism and Machine Theory, Vol. 45, No. 11, pp.1583-1598.

\section{МОДЕЛИРАЊЕ ЗА ПОЈЕДНОСТАВЉЕЊЕ ДИЗАЈНА И ПОБОЉШАҢЕ ЕФИКАСНОСТИ ПРОТОКА СНАГЕ КОД АУТОМАТСКЕ МЕЊАЧКЕ КУТИЈЕ СА ПЛАНЕТАРНИМ ПРЕНОСНИЦИМА: ПРИМЕР ЈЕДНОГ СЛУЧАЈА}

\section{С. Тамада, М. Чандра, П. Патра, С. Мандол, Д. Батачарџе, П.К. Дан}

Рад приказује метод за поједностављење дизајна и побољшање протока снаге код аутоматске мењачке кутије са планетарним преносницима. Интегрисани CAD-CAE модел, израђен према приказаном стик дијаграму рада система преносника, је развијен да би се добила конфигурација ефикасности мењачке кутије. У раду се даје пример стик дијаграма тростепеног планетарног мењача. САЕ симулацијом динамичке анализе је одређена деформација код система преносника. Избор модела возила SATURN SL1 је извршен према NREL ADVISOR. Ефикасност протока снаге за сваки преносни однос је израчунат применом ДелКастиљовог принципа а анализа деформације је извршена да би се одредио одговарајући преносни однос. Утврђено је да мењачка кутија пројектована са пет преносних односа је ефикаснија од кутије са седам преносних односа.

Развијени модел је тестиран коришћењем MATLAB софтвера, са Новим европским радним циклусом, да би се одредио најбољи број преносних односа. Утврђено је да се највећа ефикасност постиже вожњом од друге до четврте брзине. Предложени приступ одређује услове вожње и ефикасност код пројектовања мањачке кутије. 